\title{
Resource-building structures hydraulic account for treatment of vehicle washing stations wastewater
}

\author{
Aybek Arifjanov ${ }^{1}$, Uchqun Umarov $^{2 *}$ and Akmal Abdullayev ${ }^{2}$ \\ ${ }^{1}$ Tashkent Institute of Irrigation and Agricultural Mechanization Engineers, Tashkent, Uzbekistan \\ ${ }^{2}$ Tashkent State Transport University, Tashkent, Uzbekistan
}

\begin{abstract}
The article presents a method for calculating the parameters of treatment facilities to bring the level of precipitation and wastewater from small enterprises, shops, and services of the Republic to the level of sewage and irrigation trays. The aim is to improve the design parameters of resource-efficient wastewater treatment plants and their widespread use, increase the production capacity of local wastewater treatment plants, improve the level of wastewater treatment and prevent environmental degradation. Hydraulic calculation of the design parameters of the settling tank was carried out at the local treatment plant. The precipitator works by precipitating suspended solids and separating petroleum products from the liquid surface. At the local treatment plant, the content of petroleum products in industrial and precipitation effluents was reduced to $3 \mathrm{mg} / \mathrm{l}$, and the number of suspended solids to $1-1.5 \mathrm{mg} / \mathrm{l}$.
\end{abstract}

\section{Introduction}

It is known that as the living standards of the population improve, the material resources to meet human needs increase, and as a result, the amount of wastewater increases.

If we focus on the level of car ownership, which is one of the factors determining the population's living standards, from 2013 to 2020, the number of cars per 100 households increased from 35 to 48 . As of January 1, 2020, the number of vehicles owned by individuals in Uzbekistan amounted to 2580133. According to the State Statistics Committee cars - 2410421; trucks - 150294; buses - 5072; minibuses - 10590; special transport - 3756 units [1]:

As the number of vehicles increases, so does the number of laundries, gas stations, and workshops that service them. As of 2020, Tashkent has 10 depots and car plants, 104 gas stations, 386 car maintenance companies, 52 truck maintenance companies, 25 railway transport maintenance companies [2]. In all, industrial and storm water effluents are discharged into city sewers. While the average volume of water consumed by each of them is $3 \mathrm{~m} 3$ per day, at least $1730 \mathrm{~m} 3$ of wastewater is added to the city sewerage network per

\footnotetext{
*Corresponding author: uchqunflying@gmail.com
} 
day. This, in turn, affects the level of use of water resources of the Republic. Damage to the water content level will also increase due to the discharge of wastewater into the city sewerage network. As a result, problems such as saving natural water resources and improving their quality will increase $[3,4,7,8]$.

To study the processes of wastewater treatment of industrial enterprises and their application in the practice of natural and wastewater treatment Ya.Karelin, V.G.Ponomarev, I.V.Skirdov, A.G.Sokolov, V.V.Naydenko, V. G.Ivanov, I.S.Babaev, L.I.Volftrub, M.V.Demura, I.G.Shafi-Zade, U.A.Soatov, B.Hart'a, A.Kirby, J.Cornelissen'a, H.Eilersa, Camp, Yao, Tanaka, Brunsmann, A.M. Arifjanov, Sh.Sh. Ergashev and other Scientists have made a huge contribution.

However, despite numerous scientific studies in this area, the issues of wastewater treatment of industrial enterprises and the development of a small monobloc device, its engineering accounting, and treatment technology in local wastewater treatment plants are not sufficiently studied $[5,6]$.

Excessive amounts of suspended solids (particles) and petroleum products are discharged into the effluent from motor transport enterprises. Therefore, it is necessary to build special treatment facilities for such enterprises before discharging them into the municipal sewage and water sources $[3,4,5,6,12,14,15]$. The State Committee for Nature Protection of the Republic of Uzbekistan adopted RH 84.3.6: 2004 - "Regulation of discharge of pollutants into water basins and relief zones, taking into account the technically achievable indicators of wastewater treatment" adopted by the State Committee for Nature Protection of the Republic of Uzbekistan in 2004 Instructions for installation (working document) [3, 4]. This requirement stipulates the level of suspended solids and petroleum products in the water after the local wastewater treatment plants of road transport enterprises.

From the analysis of the work done in this direction $[5,6,9,10$,], it can be concluded that enterprises specializing in vehicle washing place several requirements in the selection of the technological scheme of local wastewater treatment plants (LWT). The use of LWT is highly wastewater treatment, energy saving, high capacity of the facility, efficient installation and operation processes, low cost of construction, the low area required in the existing area, relatively inexpensive tools and technical parts during operation, and longterm use has a number of advantages, such as performance from materials [4, 5].

At present, the enterprises specializing in the washing of vehicles in the territory of Uzbekistan LWT are more foreign-made products and products of joint ventures, the import, installation, and repair of which lead to high overhead costs.

\section{Methods}

This article presents a method for calculating the new design parameters of compact monoblock LWT for wastewater of enterprises and small enterprises specializing in car washing (where oil and oil products are common in wastewater). The recommended LWT consists of the following elements: drainage pipes, clarifier (made of reinforced concrete rings for 4 sewer wells brand $\mathrm{KC10}-9$ ), rapid filter (made of reinforced concrete rings for sewer wells brand $\mathrm{KC} 20-9$ ), oil collector ( $\mathrm{KC10}-9$ brand 2 made of reinforced concrete rings for sewer wells), stainless steel reinforcing mesh (size $35 \times 35$ and 15x15, used to trap large items).

The principle of operation of the sewage LWT is as follows (Figure 1): the enterprise sewage, which specializes in car washing, has several diameters of $100 \mathrm{~mm}$ through a pipe 3 to the vertical drain 2 . Filter nets of size $10 \times 10$ are passed through 14 to trap large 
substances before the effluent is discharged into the settling tank. Subsurface substances such as sand, turbidity, and solid particles in the effluent in the settling tank are ensured to settle to the bottom of the settling $16.0 .5-1.5 \mathrm{~m}$ from the bottom of the tunnel. The effluent from the top is discharged to a rapid filter 1 through a non-metallic pipe 4 with a diameter of $250 \mathrm{~mm}$.

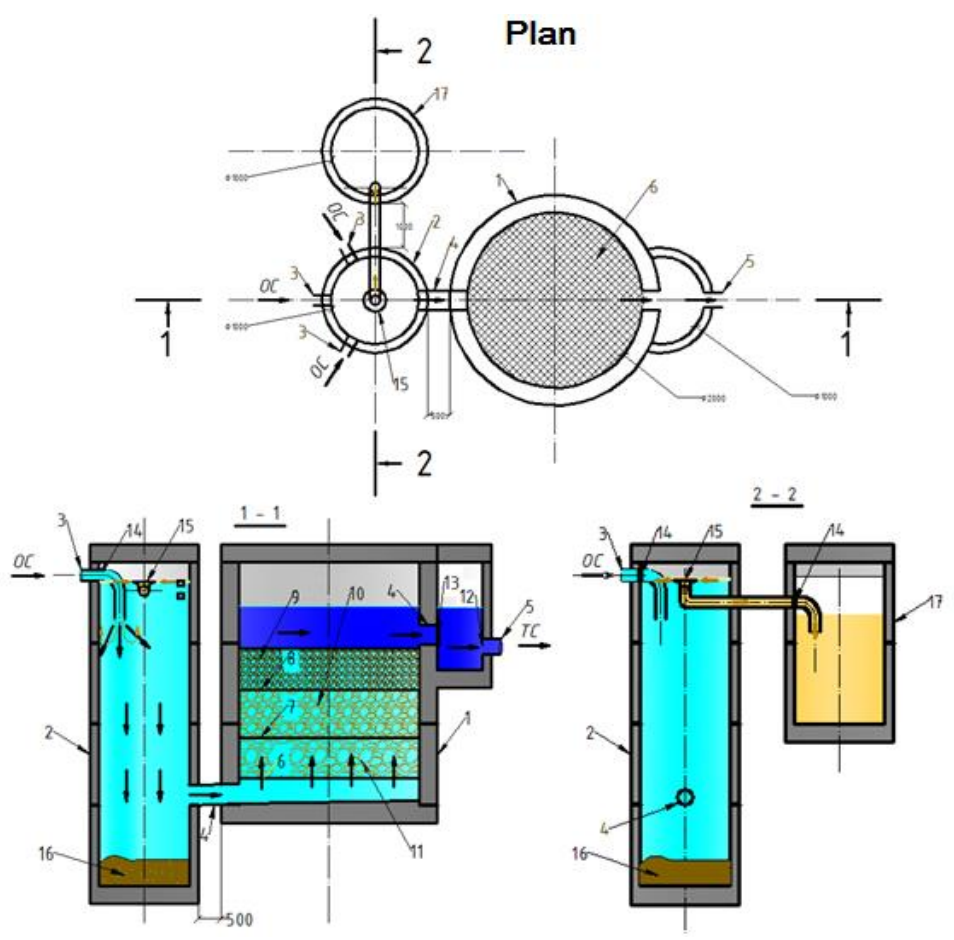

Fig. 1. Plan and schematic view of the technological scheme of the proposed compact local treatment plant with vertical clarifier and quick filter

In the instantaneous filter, the water is passed through three stages of filtration $(11,10,9$ local filter substitute), and the treated water is transferred through the discharge pipe 5 to the municipal sewerage networks or reservoirs (reservoirs) for reuse. To prevent the interference of the filtering substances in the rapid filter, special mesh catchers $6,7,8$ are installed for each of them. It is ensured that the dimensions of these mesh cells are smaller than the diameter dimensions of the filter media. Considering the emergency situation in the filter, it is necessary to install 10x10 grid handles 12 and 13 before the drain pipes.

Substances with oil-oil and a density less than the density of water in the effluent are collected in the upper part of the liquid in the separator and transferred to the collectors 17 through the chemical discharge device 15 mounted on the upper part. The collectors are periodically cleaned by special vehicles and sent to oil and waste refineries.

It takes 15 minutes to 1 hour to wash a light car. The hourly water capacity of car washers is 460 liters per hour (Kercher K5.55). This means that washing a car consumes a minimum of 40-50 liters of water and a maximum of 120 liters. Typically, car washes use two carriers at the same time. When washing a car (assuming an average of 20 minutes of carcher use time), the water consumption per second of a carcher is equal to: 


$$
q=\frac{W_{\max }^{\prime}}{60 \cdot T^{\prime}}, l / s
$$

Hourly water consumption of a carcher $[10,11,17]$ :

$$
Q_{h}^{\prime}=3.6 \cdot q, m^{3} / s
$$

If the operating mode is 16 hours per day, the daily water consumption of the enterprise $\mathrm{Q}_{\text {day }}$ is determined as follows:

$$
Q_{\text {day }}=T \cdot n \cdot Q_{h}^{\prime}, m^{3} / d a y
$$

where $\mathrm{n}$ is the number of working quarries in the enterprise; $\mathrm{T}$ is the daily working hours of the enterprise $(\mathrm{T}=16 \mathrm{~h})$

Depending on the amount of water consumption, it is possible to determine the hydraulic calculation of the proposed LWT sediment section. In this case, the advantages of using a vertical breaker are high.

Calculating the braking efficiency of a vertical breaker $[5,6,16,17]$ :

$$
\ni=100 \frac{C_{e n}-C_{e x}}{C_{e n}}, \%
$$

here $\mathrm{C}_{\mathrm{en}}$ is the initial concentration of suspended solids in the effluent flowing into the settling tank is equal to $400 \mathrm{mg} / \mathrm{l} ; \mathrm{C}_{\mathrm{ex}}$ is concentration of suspended solids in the effluent, which equals $200 \mathrm{mg} / \mathrm{l}$.

The calculations begin with the determination of the hydraulic size of the sediment particles $[5,6,10,16,17,21]$ :

$$
u_{0}=\frac{1000 \cdot H_{\text {set }} \cdot K_{\text {set }}}{t_{\text {set }} \cdot\left(\frac{H_{\text {set }} \cdot K_{\text {set }}}{h_{1}}\right)^{n_{2}}}, \mathrm{~mm} / \mathrm{s}
$$

where: $\mathrm{H}_{\text {set }}$ is the depth of the sediment flow passage, $\mathrm{m}$ (2-table);

$\mathrm{K}_{\text {set }}$ is the utilization factor of the capacity of the current-carrying part (Table 2);

$\mathrm{t}_{\text {set }}$ is interval duration, $\mathrm{s}$ (Table 1) [16];

$\mathrm{h}_{1}=500 \mathrm{~mm}$ is the height of the sediment layer;

$\mathrm{n}_{2}$ is level indicator, which depends on the concentration of sediment and sedimentation efficiency (up to $50-60 \%$ is acceptable for municipal sewage). It is determined according to the graph shown in Figure $2[16,18,19,20]$. 


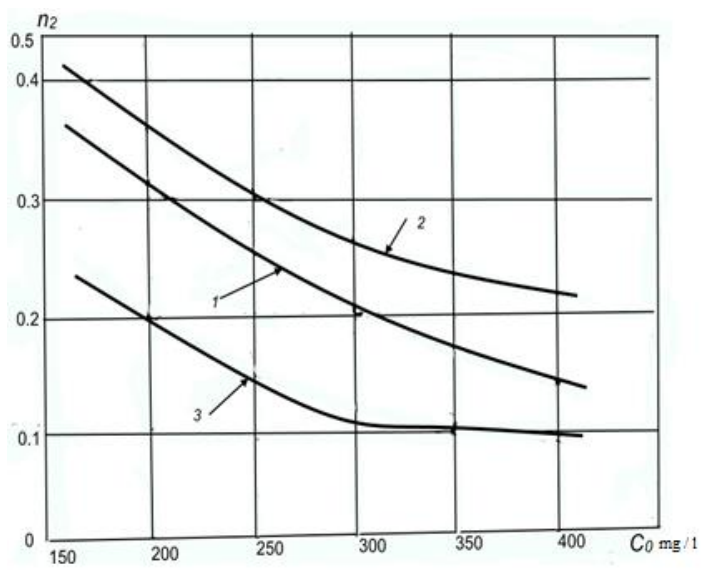

Fig. 2. $n_{2}$ indicator level according to clarification efficiency: $1-Э=50 \% ; 2-Э=60 \% ; 3-Э=70 \%$

Table 1. Duration of sewage treatment $t_{\text {set }}$

\begin{tabular}{|c|c|c|c|c|}
\hline \multirow{2}{*}{$\begin{array}{c}\text { Clarification } \\
\text { efficiency, } \%\end{array}$} & \multicolumn{5}{|c|}{$\begin{array}{l}\mathrm{h}=500 \text { when the concentration of floating substances in the mm layer is } \\
\mathrm{mg} / \mathrm{l} \\
\end{array}$} & \multicolumn{5}{|c|}{\begin{tabular}{c} 
ver \\
\cline { 2 - 5 }
\end{tabular}} & 100 & 200 & 300 & 400 \\
\hline 20 & 600 & 300 & - & - \\
\hline 30 & 900 & 540 & 320 & 260 \\
\hline 40 & 1320 & 650 & 450 & 390 \\
\hline 50 & 1900 & 900 & 640 & 680 \\
\hline 60 & 3800 & 1200 & 870 & 1830 \\
\hline 70 & - & 3600 & 2600 & \\
\hline
\end{tabular}

Sample concentrations of sediments are used in the design, and their efficiency is determined based on the initial data.

The main performance indicators are shown in Table 2 [16]. 
Table 2. Calculators of tins

\begin{tabular}{|c|c|c|c|c|c|}
\hline reducer type & $\mathrm{K}_{\text {сет }}$ & $\begin{array}{l}\text { Working } \\
\text { depth } \mathrm{H}_{\text {ceт }}\end{array}$ & Width $\mathrm{b}_{\text {cer }} \mathbf{M}$ & $\begin{array}{c}\text { Flow } \\
\text { rate } \\
\mathrm{B}_{\mathrm{w}} / \mathrm{c} \\
\mathrm{mm} / \mathrm{c}\end{array}$ & Slope \\
\hline Horizontal & 0.5 & $1.5-4$ & $2 \mathrm{H}_{\mathrm{cer}}-5 \mathrm{H}_{\mathrm{cer}}$ & $5-10$ & $0.005-0.05$ \\
\hline Radial & 0.45 & $1.5-5$ & - & $5-10$ & $0.005-0.05$ \\
\hline Vertical & 0.35 & $2.7-3.8$ & - & - & - \\
\hline $\begin{array}{c}\text { With rotary } \\
\text { assembly- } \\
\text { distribution device }\end{array}$ & 0.85 & $0.8-1.2$ & - & - & 0.05 \\
\hline $\begin{array}{l}\text { With bottom-up } \\
\text { flow movement }\end{array}$ & 0.65 & $2.7-3.8$ & - & $2 \mathrm{y}_{0}-3 \mathrm{y}_{0}$ & - \\
\hline $\begin{array}{l}\text { Schemes of working } \\
\text { with thin-layer } \\
\text { blocks } \\
\text { 1. Against the flow } \\
\text { 2. Focused on the } \\
\text { flow } \\
\text { 3. at crossroads }\end{array}$ & $\begin{array}{l}0.5 \\
0.7 \\
0.8\end{array}$ & $0.025-0.2$ & $2-6$ & - & 0.005 \\
\hline
\end{tabular}

The number of interceptors $n$ is accepted; according to the project, its number is 1 .

The diameter of the sewage inlet (central) pipe is found as follows:

$$
d_{e n}=\sqrt{\frac{4 q_{\max }}{\pi n v_{e n}}}, m
$$

here $\mathrm{q}_{\max }$ is maximum per second consumption of wastewater, $\mathrm{mm} / \mathrm{s} ; v_{\mathrm{en}}$ is the speed of movement of sewage in the sewer inlet (central) pipe is accepted, provided that it is not less than $0,03 \mathrm{~m} / \mathrm{s}$

The calculated diameter of the sewage inlet (central) pipe is rounded to the sort value $d_{\text {en }}$.

The diameter of the drill is determined by $\mathrm{D}_{\text {set }}$

$$
D_{\text {set }}=\sqrt{\frac{4000 q_{\max }}{\pi n K_{\text {set }}\left(u_{0}-v_{t b}\right)}+d_{\text {en }}^{2}}, m
$$

where $v_{\mathrm{tb}}$ is turbulence component velocity, $\mathrm{mm} / \mathrm{s}$, is taken from Table 3 [16].

Table 3. Turbulence component depending on working flow rate

\begin{tabular}{|c|c|c|c|}
\hline Workflow speed $v_{\mathrm{w}}, \mathrm{mm} / \mathrm{s}$ & 5 & 10 & $\mathbf{1 5}$ \\
\hline $\begin{array}{c}\text { Turbulence component } v_{\mathrm{tb}}, \\
\mathrm{mm} / \mathrm{s}\end{array}$ & 0 & $\begin{array}{c}0,0 \\
5\end{array}$ & $\mathbf{0 , 1}$ \\
\hline
\end{tabular}

The diameter of the inlet pipe trumpet is $d_{r}$, and the diameter of the return barrier is $d_{T}$ 


$$
\begin{aligned}
& d_{\mathrm{p}}=1.35 d_{e n}, m \\
& d_{\mathrm{T}}=1.3 d_{\mathrm{p}}, m
\end{aligned}
$$

The height between the bottom of the inlet pipe and the return barrier is calculated as $\mathrm{H}_{1}$

$$
H_{1}=\frac{q_{\max }}{\pi n d_{\mathrm{p}} v_{\mathrm{T}}}, m
$$

where $v_{\mathrm{T}}$ is the velocity of the fluid in the interval (slit) is $0.02 \mathrm{~m} / \mathrm{s}$.

The total height of the cylindrical part of the damper is $\mathrm{H}_{\mathrm{L}}$

$$
\mathrm{H}_{\mathrm{c}}=\mathrm{H}_{\mathrm{set}}+\mathrm{H}_{1}+\mathrm{H}_{2}+\mathrm{H}_{3}, m
$$

where $\mathrm{H}_{2}$ is the height of the neutral layer between the return barrier and the sedimentation layer is assumed to be $0.3 \mathrm{~m} ; \mathrm{H}_{3}$ is the height of the deck board assumed to be $0.5 \mathrm{~m}$.

The height of the conical part of the trimmer is $\mathrm{H}_{k}$

$$
\mathrm{H}_{\mathrm{k}}=0.5 \mathrm{D}_{\mathrm{set}} \cdot \operatorname{tg} \alpha, m
$$

where $\alpha$ is the size of the angle at the bottom of the conical section is assumed to be in the range of $50-60^{\circ}$.

The total height of the damper is $\mathrm{H}$

$$
\mathrm{H}=\mathrm{H}_{\mathrm{c}}+\mathrm{H}_{\mathrm{k}}, m
$$

Based on the following formula, the daily amount of sediment to be retained in the precipitator is determined by $\mathrm{Q}_{\mathrm{mud}}[18,19,20]$ :

$$
Q_{m u d}=\frac{Q_{d a y}\left(C_{e n} \cdot C_{e x}\right)}{\left(100-p_{m u d}\right) \gamma_{m u d} \cdot 10^{4}}, m^{3} / d a y
$$

where $\mathrm{Q}_{\text {day }}$ is daily consumption of waste, $\mathrm{m}^{3} /$ day; $\mathrm{p}_{\mathrm{mud}}$ is sediment moisture, is equal 94$96 \% ; \gamma_{\text {mud }}$ is sediment density, is equal to $1 \mathrm{~g} / \mathrm{cm}^{3}$.

\section{Results and Discussion}

Based on the above formulas, the parameters of the recommended LWT vertical breaker were calculated using Microsoft Excel, and the values were tabulated in Table 4. 
Table 4. Theoretically found values of the design parameters of the proposed LWT

\begin{tabular}{|c|c|c|c|c|c|c|c|c|c|}
\hline $\mathrm{C}_{\mathrm{en}}$ & $\mathrm{C}_{\mathrm{ex}}$ & $Э$ & $\mathrm{~T}^{\prime}$ & $\mathrm{W}_{\max }^{\prime}$ & $\mathrm{q}_{\max }$ & $\mathrm{Q}_{\mathrm{h}}^{\prime}$ & $\mathrm{T}$ & $\mathrm{n}_{\mathrm{k}}$ & $\mathrm{Q}_{\text {day }}$ \\
\hline $\mathrm{mg} / \mathrm{l}$ & $\mathrm{mg} / 1$ & $\%$ & $\mathrm{~s}$ & 1 & $1 / \mathrm{s}$ & $\mathrm{m}^{3} / \mathrm{h}$ & $\mathrm{h}$ & $\mathrm{ta}$ & $\mathrm{m}^{3} / \mathrm{day}$ \\
\hline 400 & 200 & 50 & 20 & 120 & 0.1 & 0.36 & 16 & 2 & 11.52 \\
\hline
\end{tabular}

Table 4 continued

\begin{tabular}{|c|c|c|c|c|c|c|c|c|c|}
\hline $\mathrm{H}_{\text {set }}$ & $\mathrm{K}_{\text {set }}$ & $\mathrm{t}_{\text {set }}$ & $\mathrm{h}_{1}$ & $\mathrm{n}_{2}$ & $\mathrm{u}_{0}$ & $\pi$ & $\mathrm{n}$ & $\mathrm{v}_{\text {en }}$ & $\mathrm{q}_{\max }$ \\
\hline $\mathrm{m}$ & & $\mathrm{s}$ & $\mathrm{mm}$ & & $\mathrm{mm} / \mathrm{s}$ & & $\mathrm{PCS}$. & $\mathrm{m} / \mathrm{s}$ & $\mathrm{m}^{3} / \mathrm{s}$ \\
\hline 2.7 & 0.35 & 450 & 500 & 0.14 & 0.505 & 3.14 & 1 & 0.03 & 0.0001 \\
\hline
\end{tabular}

Table 4 continued

\begin{tabular}{|c|c|c|c|c|c|c|c|c|c|}
\hline $\mathrm{d}_{\text {en }}$ & $\mathrm{d}_{\text {en.sort }}$ & $\mathrm{v}_{\mathrm{W}}$ & $\mathrm{V}_{\mathrm{tb}}$ & $\mathrm{D}_{\text {set }}$ & $\mathrm{d}_{\mathrm{p}}$ & $\mathrm{d}_{\mathrm{T}}$ & $\mathrm{H}_{1}$ & $\mathrm{v}_{\mathrm{t}}$ & $\mathrm{H}_{2}$ \\
\hline $\mathrm{m}$ & $\mathrm{m}$ & $\mathrm{mm} / \mathrm{s}$ & $\mathrm{mm} / \mathrm{s}$ & $\mathrm{m}$ & $\mathrm{m}$ & $\mathrm{m}$ & $\mathrm{m}$ & $\mathrm{m} / \mathrm{s}$ & $\mathrm{m}$ \\
\hline 0.065 & 0.063 & 15 & 0.1 & 0.95 & 0.085 & 0.11 & 0.02 & 0.02 & 0.3 \\
\hline
\end{tabular}

Table 4 continued

\begin{tabular}{|c|c|c|c|c|c|c|c|c|}
\hline $\mathrm{H}_{3}$ & $\mathrm{H}_{\mathrm{L}}$ & $\alpha$ & $\tan (\alpha)$ & $\mathrm{H}_{\mathrm{k}}$ & $\mathrm{H}$ & $\mathrm{p}_{\text {mud }}$ & $\gamma_{\text {mud }}$ & $\mathrm{Q}_{\text {mud }}$ \\
\hline $\mathrm{m}$ & $\mathrm{m}$ & ${ }^{2}$ & & $\mathrm{~m}$ & $\mathrm{~m}$ & $\%$ & $\mathrm{~g} / \mathrm{sm}^{3}$ & $\mathrm{~m}^{3} / \mathrm{day}$ \\
\hline 0.5 & 3.52 & 50 & 1.19 & 0.565205 & 4.08 & 95 & 1 & 0.046 \\
\hline
\end{tabular}

\section{Conclusions}

Advantages of the proposed LWT: all the necessary technical parts and raw materials for the construction are the products of local manufacturers, low cost of transport and raw materials, energy efficiency in wastewater treatment, purified water content for water sources, and reusability.

The created LWT can be used in car washes, car depots, and small enterprises for the treatment of wastewater from petroleum products and suspended solids. In this case, the LWT treats the content of wastewater to the extent specified in the regulations.

The height and diameter of the drill determined in the calculations are optimal for practical use. The reason is that the main collectors of municipal sewage are usually laid at a depth of 3-5 $\mathrm{m}$ above ground level. The height of the culvert $(\mathrm{H}=4.08 \mathrm{~m})$ determined in the calculation corresponds to the depth at which the sewer collectors are laid. Compliance with the assortment of reinforced concrete rings for sewer wells brand $\mathrm{KC10-9}$, the size of which is determined by the diameter of the trough $(\mathrm{D}=0.95 \mathrm{~m})$, guarantees the effectiveness of the design for installation and operation.

\section{References}

1. Portal of the State Statistics Committee of the Republic of Uzbekistan, https://stat.uz/uz/ochiq-ma-lumotlar/180-ofytsyalnaia-statystyka-uz/ 6554.

2. Tashkent map online, My City, Mg.uz, www.mg.uz.

3. State Committee of the Republic of Uzbekistan for Nature Protection. Guidance document. Protection of Nature. Instruction on the regulation of discharges of pollutants into water bodies and onto the terrain, taking into account technically achievable indicators of wastewater treatment.: O'z RH 84.3.6: - p.34. Tashkent (2004)

4. State Committee of the Republic of Uzbekistan for Nature Protection. Guidance document. Protection of Nature. Guidelines for calculating the norms of maximum 
permissible discharges of pollutants into water bodies and onto the terrain, taking into account technically achievable indicators of wastewater treatment. Official edition.: O'z RH 84.3.5: 2004.- p.33. Tashkent, (2004)

5. D.e.s., prof. A.M.Ariphjanov, Sh.Sh. Ergashev.: Estimation of efficient operation of the monoblock unit and treatment of the sewage waters. International Journal of Advanced Research in Science, Engineering and Technology. ISSN: 2350-0328. IJARSET Vol. 6, Issue 5, (05.00.00; №8), May (2019)

6. Ergashev Sh.Sh. Improvement of local treatment facilities of railway transport enterprises of the Republic of Uzbekistan. Bulletin of TashIIT, issue 1. (2014) Tashkent. pp.25-29. (05.00.00; №11).

7. Samiyev, L., Allayorov, D., Atakulov, D., Babajanov, F. The influence of sedimentation reservoir on hydraulic parameters of irrigation channels (2020) IOP Conference Series: Materials Science and Engineering, 883 (1), DOI: 10.1088/1757899X/883/1/012031.

8. Fatxulloyev, A., Abduraimova, D., Otakhonov, M., Atakulov, D., Samiev, L. Method designing of open drainages (2020) IOP Conference Series: Materials Science and Engineering, 883 (1),.DOI: 10.1088/1757-899X/883/1/012047.

9. Rustamov, G.S., O'Rinova, A.A., Bo'Riev, S.S., Samiev, L., Madaminov, R., Ismayilova, I., Annamuratova, D., Jumanazarova, N. The effectiveness of biological treatment of domestic wastewater on the example of treatment facilities in the city of bekabad, Tashkent region European Journal of Molecular and Clinical Medicine, 7 (11), pp. 267-276. (2020)

10. Alekseev M.I., Ivanov V.G., Kurganov A.M., Medvedev G.P., Mishukov B.G., Feofanov Yu.A., Tsvetkova L.I., Chernikov N.A. - Scientific editors. Technical guide to water treatment: in 2 volumes. with fr. The team of authors is the employees of Degremon and Ondeo Industrial Solutions. - SPb .: New magazine. - p.1737 (2007)

11. Ivanov V.G., Chernikov N.A. Drainage systems of industrial enterprises. SPb: LLC "Publishing house" OM-Press ".-p.244, (2007)

12. Sewage. Narujnye seti i soorujeniya. KMK 2.04.03-97. Goskomarkhitektstroy RUz. T. - p.115, (1997)

13. Laskov Yu.M., Voronov Yu.V., Kalitsun V.I. Primerb raschetov kanalizatsionnyx soorujeniy, M., Stroyizdat. - p.254, (1987)

14. About water and water supply - Law of the Republic of Uzbekistan. Postanovlenie Verkhovnogo Soveta Respubliki Uzbekistan № 837- XII от 06.05.1993 г. (v ed. № 568-II dated 12.12.2003.)

15. SanPiN № 0056-96. Hygienic criteria of quality of drinking water. Tashkent. (1996).

16. A.G. Gudkov. Mexanicheskaya ochistka stochnyx vod, Vologda: VoGTU, ISBN 587851-225-4, - p.152, (2003)

17. Yakovlev S.V., Voronov Yu.V. Branch and clearing stochnyx vod. Textbook for universities: -M.: Association of stroitelny universities. - p.704, (2002)

18. Arifzhanov, A.M. Method for calculation of the distribution of drift particles in variable section beds (VSB). Gidrotekhnicheskoe Stroitel'stvo. Issue 2, (2004), pp.4445. ISSN: 00169714.

19. Aybek Arifjanov, Shamshodbek Akmalov, Islombek Akhmedov, Dinislom Atakulov Evaluation of deformation procedure in waterbed of rivers. XII International Scientific Conference on Agricultural Machinery Industry. IOP Conf. Series: Earth and Environmental Science 403 (2019) 012155. DOI: 10.1088/1755-1315/403/1/012155.

20. Aybek Arifjanov, Sherali Juraev, Luqmon Samiev, Zaytuna Ibragimova, Farruh Babajanov Determination of Filtration Strength and Initial Filtration Gradient in Soil Constructions. Jour of Adv Research in Dynamical \& Control Systems, Vol. 12, 04Special Issue, 2020. DOI: 10.5373/JARDCS/V12SP4/20201672. 
21. Fatxulloyev, A., Abduraimova, D., Otakhonov, M., Atakulov, D., Samiev, L. Method designing of open drainages (2020) IOP Conference Series: Materials Science and Engineering, 883 (1). DOI: 10.1088/1757-899X/883/1/012047. 